\title{
Trade Secrets Protection and Corporate Tax Avoidance
}

\author{
Hamid Sakaki \\ Central Connecticut State University \\ Karn Thapar \\ Central Connecticut State University
}

This paper examines the relationship between an increase in legislative trade secrets protection and its effect on tax avoidance. First, we show that the adoption of the UTSA, by itself, does not have any effect on tax avoidance activities by firms located in UTSA states. However, our research demonstrates a negative association between large firms located in UTSA states and the accompanying tax avoidance by these firms. Additionally, we document the differences in tax avoidance activities by companies in different industries. Namely, we find that large high-technology companies engage in less tax avoidance as compared to companies in other industries.

\section{INTRODUCTION}

Every company has certain information that it vehemently protects. It engages in this vehement protection so that it can establish and maintain its competitive advantage. Included in this category of vehemently protected items is "intellectual property," which are works created by the human mind that do not have a tangible form.

In this study, we explore the effect between the adoptions of the Uniform Trade Secrets Act (hereafter UTSA) among the several states to isolate the effect of trade secret protection on corporate tax avoidance. The UTSA has significantly increased trade secret protection by passing specific legislation that protects firms holding such secrets (Sandeen, 2010). Namely, the UTSA is meant to identify gaps in common law protection for trade secrets and specifically define what constitutes trade secret misappropriation. Moreover, the Act specifically defines what constitutes a trade secret and what rights firms have against misappropriation by others.

Intellectual property generally falls into one of four categories: patents, copyrights, trademarks and trade secrets. Each of these categories has its own unique legal framework that governs its administration. Patents are governed by federal law (35 U.S. Const. § 1-390) and generally refer to new and useful inventions, machines, processes and permutations of existing inventions (35 U.S. Const. $\S$ 101). Copyrights are also governed by federal law (17 U.S. Const. $\S 101-1332$ ) and generally apply to original literary, musical and artistic works (17 U.S.C. $\S \S 102-103,2000)$. Trademarks, like patents and copyrights, are governed by federal law and generally refer to a grab-bag of different items, including words, phrases and symbols that denote a particular individual or a company (15 U.S.C. $\S 1051-1141 \mathrm{n}$ ). Trade secrets, the final group, are the outlier of the bunch because they are generally governed at the state 
level rather than the federal level. They are governed by a combination of state law and common law, and refer to any information held by a company that is valuable to that company, including formulas, methods, customer lists and recipes (Uniform Trade Secrets Act $\S 1(4)$ ). We will be focusing on trade secrets for the purpose of this article.

Although it may be contrary to popular belief, surveys indicate that company executives rank trade secrets as the most important of their business' intellectual property (National Science Foundation, National Center for Science and Engineering Statistics, and U.S. Census Bureau, Business R\&D and Innovation Survey, 2013. For more details please refer to Appendix B). The strongest indication of this is found within the annual Business Research and Development Innovation Survey (BRDIS) conducted by the National Science Foundation's National Center for Science and Engineering. The BRDIS targeted for-profit companies with (a) at least five or more paid employees (b) a minimum of one business establishment in operation during the survey year and (c) performing some form of R\&D activity all within the United States.

Executives were asked, on a scale of "not important" to "very important," how important they felt each of the four categories of intellectual property were to their businesses (Form BRDI-1, 2013, p.45). Across all industries, the highest importance was given to trade secrets, with roughly $57 \%$ of executives reporting that trade secrets were "very important." This was followed by $51 \%$ for utility patents, $44 \%$ for trademarks, $27 \%$ for copyrights and $25 \%$ for design patents (id). Moreover, when looking specifically at large companies with 10,000 or more domestic employees and some R\&D expenditure, a lofty $81 \%$ of executives found that trade secrets were "very important." Table 1 reports the responses of the annual Business Research and Development Innovation Survey (BRDIS) question (How important to your company were the following types of intellectual property protection?) conducted by the National Science Foundation's National Center for Science and Engineering. The BRDIS targeted for-profit companies with (a) at least five or more paid employees (b) a minimum of one business establishment in operation during the survey year and (c) performing some form of R\&D activity all within the United States. Number 1, 2 and 3 indicates the level of importance as very important, somewhat important and not important, respectively. Size id defined as the number of domestic employees. We classified size to three groups by averaging the reported BRDIS percentages for companies with $5-499$ and $500-999$, $1,000-4,999$ and 5,000-9,999, and 10,000-24, 999 and 25,000 or more domestic employees.

TABLE 1

IMPORTANCE OF DIFFERENT IP MECHANISM TO U.S

\begin{tabular}{|c|c|c|c|c|c|}
\hline \multirow[b]{2}{*}{$\begin{array}{c}\text { Intellectual property } \\
\text { type }\end{array}$} & \multirow[b]{2}{*}{$\begin{array}{l}\text { Level of } \\
\text { importance }\end{array}$} & \multicolumn{4}{|c|}{ Importance by size (\%) } \\
\hline & & $\begin{array}{c}\text { All } \\
\text { companies }\end{array}$ & $\begin{array}{l}5- \\
999 \\
\end{array}$ & $\begin{array}{l}1,000- \\
9,999\end{array}$ & $\begin{array}{l}10,000 \text { or } \\
\text { more }\end{array}$ \\
\hline \multirow{3}{*}{ Trade secrets } & 1 & 57 & 56 & 68 & 81 \\
\hline & 2 & 20 & 23 & 21 & 13 \\
\hline & 3 & 23 & 21 & 11 & 7 \\
\hline \multirow{3}{*}{ Utility patents } & 1 & 51 & 49 & 65 & 73 \\
\hline & 2 & 16 & 18 & 17 & 15 \\
\hline & 3 & 33 & 33 & 18 & 12 \\
\hline \multirow{3}{*}{ Trademarks } & 1 & 44 & 47 & 70 & 82 \\
\hline & 2 & 31 & 30 & 20 & 13 \\
\hline & 3 & 25 & 23 & 10 & 5 \\
\hline \multirow{3}{*}{ Copyrights } & 1 & 27 & 27 & 35 & 44 \\
\hline & 2 & 34 & 35 & 42 & 44 \\
\hline & 3 & 39 & 38 & 23 & 12 \\
\hline \multirow{3}{*}{ Design patents } & 1 & 25 & 24 & 26 & 28 \\
\hline & 2 & 27 & 28 & 31 & 41 \\
\hline & 3 & 48 & 48 & 43 & 31 \\
\hline
\end{tabular}


Tax avoidance has increased among firms dramatically. So, scholars have a vested interest in identifying the determinant of tax avoidance. Literature shows that several factors can affect tax avoidance. For example, governance and executive compensation (Phillips, 2003; Desai and Dharmapala, 2006; Rego and Wilson, 2012), financial characteristic (Gupta and Newberry, 1997; Rego, 2003; Graham and Tucker, 2006; Lisowsky, 2010) and ownership structure (Chen et al., 2010; Cheng et al., 2012) are some of these factors. However, there is no evidence on how trade secrets protection affect corporate tax avoidance.

This paper will add to past research in the area of trade secrets protection and take it a step further. Namely, we will look to identify the connection between increased trade secret protection and its effect on tax avoidance. We will analyze the impact of this protection by comparing tax avoidance activities by companies headquartered in states with strong protection to tax avoidance activities by companies headquartered in states with weaker protection. Given the evidence of positive future outlook by companies in terms of greater R\&D activity and financial leverage, we expect that greater protection will also lead to a drop in tax avoidance. We formulate this opinion because we believe that when companies feel that their secrets are protected, they will feel better about their future prospects, and they will therefore have less need to skirt the law and engage in tax avoidance.

This paper offers numerous contributions in the area of business research. First, we offer new and compelling evidence on the impact of trade secret protection (namely the UTSA) on tax avoidance of firms. We are the first to make this causal connection.

Our research adds to the existing research utilizing the UTSA as an external source of secrecy variation. Other topics of papers in this area include the UTSA's effect on financial leverage for large firms (Guernsey, 2017), on R\&D expenditure (Png, 2017), on internal patenting (Png, 2016) and on financial disclosure (Guo et. al, 2016). Furthermore, we broadly contribute to literature on trade secrets protection, which has, thus far, primarily focused on the Inevitable Disclosure Doctrine (IDD). This doctrine differs from the UTSA in two ways. First, the UTSA is written into law whereas the IDD is a doctrine utilized by courts to reach a particular conclusion. Second, the UTSA focuses on the remedies which firms have for the misappropriation of trade secrets, whereas the IDD decreases the mobility of workers with access to trade secrets who are looking to join a rival firm. Papers using the IDD in exploring trade secrets protection include the impact of the IDD on capital structure decision making (Klasa et. al, 2017), short-term value implications (Qui and Wang, 2017), employee mobility by level of education (Png and Samila, 2015), internal patenting activity (Contigiani et. al, 2016), mergers and acquisitions activity (Gao and Ma, 2016) and operational uncertainty (Lin et. al, 2016). Moreover, we broadly contribute to the literature involving tax avoidance. (e.g. Gupta and Newberry, 1997; Rego, 2003; Phillips, 2003; Graham and Tucker, 2006; Desai and Dharmapala, 2006; Lisowsky, 2010; Chen et al., 2010; Cheng et al., 2012; Rego and Wilson, 2012; Huang et al., 2016; Cen et al., 2016).

Overall, our results suggest that there is a negative correlation between large firms located in states that have adopted the UTSA and the accompanying tax avoidance by these firms. We examine tax avoidance by analyzing the state-staggered implementation of the UTSA. While the adoption of the UTSA, by itself, does not have any effect on tax avoidance activities, we demonstrate a negative effect when viewed through the lens of large firms. Additionally, this paper documents the differences in tax avoidance activities by companies in different industries. Namely, large high-technology companies located in UTSA states engage in less tax avoidance as compared to companies in other industries.

We organize the remainder of this paper in this order; literature review and hypothesis development is followed by the sample selection and variables, while research design, methodology, results and summarize model outputs and conclusion are presented after that. 


\section{LITERATURE REVIEW AND HYPOTHESIS DEVELOPMENT}

Previous studies (Graham and Tucker, 2006; Hanlon and Slemrod, 2009; Desai and Dharmapala, 2009; Hanlon and Heitzman, 2010) suggest that firms can take advantage of tax avoidance by increasing their firm value through tax savings and increasing shareholders' wealth. However, firms may bear direct costs of tax avoidance such as administrative costs, litigation expenses, and penalties imposed by tax authorities (Wilson, 2009) or indirect costs such as reputation losses, higher stock price crash risk and higher cost of debt (Hanlon and Heitzman, 2010 , Kim et al., 2011; Hasan et al., 2013). So, it is safe to assert that tax avoidance is a real double-edged sword for firms. Indeed, tax avoidance can increase firm value, if its advantages outweigh the potential costs. Therefore, identifying the determinants of tax avoidance is important. Literature identifies some factors that can affect tax avoidance. Recently, Huang et al. (2016) show that there is a positive and significant relationship between the level of customer concentration and the extent of tax avoidance. In addition, Cen et al. (2016) suggest that tax avoidance activities through supply chains is more prevalent in firms with close customer-supplier relationships.

In this study, we consider the impact of trade secret protection on corporate tax avoidance. To the best of our knowledge nobody has been focused on the association between trade secrets protection and corporate tax avoidance.

There exists research exploring the connection between the level of protection afforded to companies' trade secrets and the level of financial leverage and innovative activity within these companies. As to the first point, financial leverage, Guernsey (2017) has found that greater trade secret protection invariably leads to increased financial leverage, especially among large companies. He found that companies increased financial leverage largely as a result of decreased bankruptcy costs, which were the result of greater trade secret protection. As to the second point, innovative activity, Png (2017) has found that a positive correlation exists between greater trade secret protection and R\&D among both large firms and firms within high-technology industries. Moreover, Png (2016) indicates that that fewer companies apply for patents when laws afford them with greater trade secret protection.

Png's $(2016,2017)$ study, when coupled with Guernsey's (2017), leads to the conclusion that when laws and regulations increase trade secret protection for companies, they are more positive of their future prospects. This conclusion can be drawn because these companies not only increase funding for R\&D activity, which is by its nature optional, but they also feel comfortable taking on additional debt.

There is at least one way in which trade secrets protection could affect tax avoidance by large firms. Prior research has found other situations in which trade secrets protection could affect tax avoidance. Namely, it has found that when firms are afforded greater protection, they may be at less risk of other firms in the same industry or sector misappropriating their trade secrets. For example, given the difficulty in protecting trade secrets, there are certain counter-intuitive situations in which other firms could receive legal protection for the original firm's trade secret. Take for example the situation in which a competitor firm discovers the trade secret through reverse-engineering (Png, 2017). If that firm were to thereafter seek and successfully obtain a patent for the secret that firm would be entitled to legal protection for that secret (Jaffe 1986, and Hall et al. 2014). Surprisingly, the firm in which the trade secret originated would thereafter be prohibited from utilizing the information derived from that trade secret. As such, if a firm were located in a jurisdiction with greater protection for trade secrets, such a result would be avoided and the trade secret would remain under the strict control of the original firm. Consequently, large firms headquartered in these jurisdictions would be less likely to engage in tax avoidance because the trade secret, and the income produced therefrom, would be protected and they would be less likely to seek other means (especially illegal means) of increasing their income.

\section{INSTITUTIONAL BACKGROUND}

\section{Trade Secrets Protection under the Common Law}

Broadly speaking, trade secret law falls under the branch of law that deals with unfair competition. In order to make out an action for unfair competition, one must satisfy the elements required for any "tort" 
or civil wrong. Namely, an injured party must prove that it was harmed by the acts of another and that it is entitled to remedies for the injury inflicted. Early on in the course of unfair competition law, courts generally found that free competition outweighed a businessman's hindered ability to run his business (Restatement (First) of Torts, 1934; Restatement (Third) of Unfair Competition, 1995). However, over time, businessmen were able to convince courts that free competition did not permit unfair competition, as the two were fundamentally at odds (Restatement (First) of Torts, 1939; Nims, 1947; Callman, 1940; Ellis, 1953). As such, courts began to find a cause of action for unfair competition and specifically for trade secret misappropriation.

Early trade secret law focused on three forms of wrongdoing. These were: (1) discovery by improper means; (2) acquisition of the secret by a third party with notice of the fact of secrecy and the duty of confidentiality; and (3) acquisition of the secret with notice of the fact of secrecy and knowledge that it was disclosed by mistake (Restatement (First) of Torts, 1934). However, what is of particular note is that the details of these three causes of action were not clearly defined and courts were indirectly charged with using common law principles to define these causes of action.

As trade secret law began to gain stronger footing, it could have remained within the purview of the common law like other torts. In fact, there were plenty of judicial decisions and treatises written on the subject, so it would have been reasonable for it to remain there (Ellis, 1953; Nims, 1947; Harvard Law Review, 1964; Milgrim, 1968). However, uniform lawmakers and legislatures saw the value in adding uniformity to trade secret law across the several states and decided to codify a set of laws concerning their misappropriation. They saw value in passing such laws because of the slow pace and inconsistent development of the common law for trade secrets, which led to major anguish on the part of business people. As such, the UTSA came into existence.

\section{The Uniform Trade Secrets Act}

The UTSA, as a state-level trade secret law, is the focus of this article because it allows us to connect increased trade secret protection at the state level to the tax avoidance of firms headquartered in those states with this increased protection. It should be noted that there are laws governing trade secrets at the federal level as well, such as the Defend Trade Secrets Act, but we will not be analyzing such laws because we proxy for tax avoidance by comparing firms that are headquartered in states with increased trade secret protection against firms that that are not headquartered in such states. If we were to consider federal laws, it would not allow us to differentiate these firms because federal law applies to all states. As such, federal legislation will be excluded from the purview of this article.

The UTSA refined and improved trade secret law in at least six ways: (1) it provided a precise and limited definition of a trade secret; (2) it excluded protection for business information not meeting the definition of a trade secret; (3) it focused attention on the need of a trade secret claimant to prove both the existence of a trade secret and one or more acts of misappropriation; (4) it clarified the availability and scope of remedies, including injunctive relief, punitive damages, and attorneys' fees; (5) it recognized the value of protective orders during trade secret litigation; and (6) it explicitly preempted other common law causes of action designed to provide remedies for the misuse of business information (Sandeen, 2010). Although each of these improvements were important, the most consequential were the first, third and fourth.

The first primary improvement was that the UTSA addressed the common law's lack of a uniform definition for a trade secret. Prior to the passage of the UTSA, judges were directed to consider six nonexclusive factors to determine whether something was a trade secret (Restatement (First) of Torts, 1934). This led to inconsistent treatment, as some judges applied all six of the factors while others only applied one or two (Correa, 1963). The UTSA thus alleviated this problem by creating three mandatory requirements (Uniform Trade Secrets Act $\S 1$ ). First, the information must be "secret," meaning that it is not generally known or readily ascertainable. In fact, even if a company expends significant time, money, and energy to compiling certain information, it will not transform that information into a trade secret if that information is generally known. Second, the information must derive independent economic value from not being generally known. This element was added in order to ensure that businesspeople did not 
seek protection for illusory information or information of little importance. Third, the holder of such information must take reasonable steps to maintain the secrecy of such information.

The second primary improvement was that the UTSA clearly delineated what constituted an act of misappropriation by defining two routes through which misappropriation could occur. First, it could occur where a third party acquired a trade secret with knowledge, or reason to know, that it was acquired by improper means (Uniform Trade Secrets Act $\S 1(2)(i)$ ). Second, it could occur where a third party discloses or uses a trade secret with knowledge, or reason to know, that the trade secret was either (a) derived from improper means (b) derived from a person who owed a duty to maintain its secrecy or (c) acquired by a person who knew, or had a reason to know, that it was acquired by accident or mistake (Uniform Trade Secrets Act § 1(2)(ii)(B)(III), 1(2)(ii)(B)(III), 1(2)(ii)(C)).

The third primary improvement was that the UTSA clarified the scope and range of remedies available if a trade secret was misappropriated. Recognizing that businesses might find themselves as either plaintiffs or defendants in a trade secret claim, the UTSA took a balanced approach in offering remedies under the Act. First, an award for punitive damages for trade secret misappropriation was capped at twice the actual damages (Uniform Trade Secrets Act $\S 4$ ). Second, attorney fees were only granted in the case of bad faith or willful and malicious appropriation (Uniform Trade Secrets Act § 4). Third, injunctions were permitted, but protection for good faith acquirers who did not know that the trade secret was misappropriated was kept intact (Transcript of Proceedings in Committee of the Whole, 1985).

\section{The Inevitable Disclosure Doctrine ("IDD")}

No discussion of state-level trade secret protection would be complete without understanding the Inevitable Disclosure Doctrine. The IDD evolved from trade secret common law and provide companies an avenue by which they could block a departing employee from working for a competitor. Although it is not accepted by every state as the law, it has been used by a number of courts in the furtherance of trade secret protection.

Businesses are understandably worried when an employee with trade secret information decides to join a competitor. This is especially the case when the employee has not signed a non-compete agreement (agreement to not work for or become a competitor) or a non-disclosure agreement (agreement to not disclose confidential company information) before departing. The concern is that in working for the competitor company, the departing employee will inevitably use or disclose trade secrets that it acquired while in the employment of the former company. Thus, by using the IDD, the company can obtain an injunction to stop the departing employee from joining the competitor company.

A company seeking to make a claim under the IDD essentially has to meet the requirements of Section 2 of the UTSA which states that there must be "actual or threatened misappropriation (Uniform Trade Secrets Act $\S 2$ )." This is somewhat ambiguous and the courts' application of this principle has been inconsistent. Nonetheless, if a court does apply the IDD, it will find that if a high-ranking employee takes a job with a competitor, the threat of misappropriation could be implied. As such, an injunction forbidding the move could be issued. Courts argue that this is in the best interests of businesses because departing employees will be less likely to intentionally or unintentionally disclose or use the trade secrets of a former employer (Brenner, 2001). As such, businesses will be less likely to try to poach high-level employees from competitors, thereby allowing businesses to retain key employees. Additionally, courts believe that in applying the IDD, innovation will be encouraged because additional protection for trade secrets is being provided (Jager, 1988; Pace, 1995). As such, companies will not only feel freer to entrust important information to their employees, but they will invest money in new technologies (Roberson, 2001).

\section{Comparing UTSA and IDD}

Trade secret protection for companies are largely governed at the state level. The UTSA and IDD both provide state-level trade secret protection, but they differ greatly in their scope and their formation. Both protections originated in the common law under state court decisions, but only the UTSA has been codified by state legislatures. In fact, forty-six states have passed the UTSA, and the remaining four 
states either have legislation similar to the UTSA or are in the process of passing similar legislation. Massachusetts and New York have recently introduced legislation for trade secret protection, and North Carolina and Wisconsin have laws similar to the UTSA already in place.

The IDD, conversely, has not been codified in law and is not currently under review by any state legislature. Rather, it has been used by some state courts as a doctrine to prevent employees with trade secrets from working with a competitor company. To date, twenty-one states have adopted this doctrine and have used it to some extent. It is our position that the laws encompassed within the UTSA will grow and strengthen, with court decisions continually refining and strengthening the UTSA. Conversely, we believe that the IDD will ultimately fall out of favor with a greater number of states because it is an unevenly and ambiguously applied doctrine. Additionally, it is of note that the IDD greatly restricts employee mobility, which stands in stark contrast to the general American presumption that employment is at will and qualified workers have the right to work wherever they choose.

\section{SAMPLE SELECTION AND VARIABLES}

\section{Data Source and Sample Selection}

The final sample includes 18,449 firm-year observations from 1979 to 1998 , excluding utilities and financial companies (SIC codes 4900-4999 and 6000-6999, respectively), headquarted in U.S. To be included in the final sample, observation must have complete data on trade secret index and Compustat. Trade secret protection index (UTSA) is obtained from the Png (2017) study. This data is available at: https://dataverse.harvard.edu/dataset.xhtml?persistentId=doi:10.7910/DVN/BFP2IC. This index is constructed by Png (2017). We obtain annual financial and accounting data to estimate dependent and control variables from the Compustat.

\section{Main Explanatory Variables}

Trade Secrets Protection Measure

Following Png (2017), we used state-level trade secrets protection index (Please refer to appendix B, which is a reproduction of Table A2 in the appendix of Png (2017), for a detailed account of the dimensions and items) to capture the change in strength of trade secrets protection due to enactment UTSA. The change due to enactment of UTSA is the difference between the index pre and post enactment. This index is constructed based on six criteria (for more details see appendix B). The index is the sum of the scores for each of the six items divided by six. So, it is a continuous variable and scaled between 0 and 1 . Higher values indicate stronger legal protection of trade secrets.

\section{Firm Size}

As it is shown in Table 1, the importance of intellectual property is increasing as the number of domestic employees is increasing. Moreover, Png (2017) show that UTSA by itself doesn't have any significant effect on R\&D expenditure. However, the interaction between the firm size and UTSA has positive and significant effect on R\&D expenditures. In addition, Figueroa and Serrano, 2013) show that as larger firms are more relying on secrecy than do small firms, they are more likely to be impacted by the change in trade secrets protection. Putting all together and following Png (2017), we consider the interaction of frim size and UTSA as the main explanatory variable as UTSA by itself can't capture the impact of trade secrets protection on corporate tax avoidance activities. We consider two proxies for firm size. The first proxy is the natural logarithm of sales. The second proxy is the natural logarithm of one plus numbers of employees. As we are considering the interaction of two continuous variable, we center firm size (employees) which is the difference between firm-year sales (employees) and its sample mean.

\section{Tax Avoidance Measures}

Following Hanlon and Heitzman (2010), we define tax avoidance as any corporate activity that leads to the reduction in a firm's explicit taxes. We construct three alternative measures of tax avoidance that have been widely used in the literature. These three measures are based on effective tax rate (ETR). 
Following prior research (e.g. Hanlon and Heitzman, 2010 and Cen et al. 2016), our first effective tax rate is GAAP effective tax rate (GAAP ETR), defined as total income tax expense divided by pre-tax book income less special items. GAAP ETR captures tax avoidance activities resulting from permanent tax savings. However, it does not capture tax avoidance activities that defer cash taxes (e.g., more accelerated depreciation for tax purpose), while CASH ETR captures tax deferral strategies (Dyreng et al., 2008). Following literature (e.g. Dyreng et al., 2008; Cheng et al., 2012; Cen et al. 2016; Huang et al. ,2016), cash effective tax rate (CASH ETR) is defined as cash taxes paid divided by pre-tax book income less special items. Indeed, CASH ETR, captures tax deferral strategies by using cash taxes paid in the numerator.

For both measures, lower values are associated with greater tax avoidance activities. Moreover, both of the tax effective measures require the denominator to be positive. Therefore, we eliminate firm-year observations with negative pre-tax income, which may lead to bias.

\section{Control Variables}

To control for the effects of firm-specific variables on the tax avoidance activities, we identify many control variables following previous literature. The first control variable is firm size (SIZE). Although previous literature show that firm size is an important determinant of tax avoidance, their findings are inconclusive (Mills, 1998; Rego, 2003; Higgins et al., 2015). The second control variable is financial leverage (LEV). On the one hand, firms can take advantage of tax-deductible interest. So, leverage leads to lower tax avoidance activities. On the other hand, highly levered firms may have more tendency to engage in tax avoidance activities in order to save cash to pay off their debt (Graham and Tucker, 2006; Badertscher et al., 2013). Also, we include market-to-book ratio (MTB) as a proxy for the firms' growth rate. Growth firms usually buy more assets and consequently have larger amortization and depreciation tax deductions (Chen et al., 2010; Cheng et al., 2012). Moreover, return on assets (ROA) as a proxy for profitability is another control variable. More profitable firms may have more resources and can use tax deductions and credits to lower their tax rates (Manzon and Plesko, 2002; Rego, 2003; Frank et al., 2009; McGuire et al., 2012).

In addition, we consider foreign income, property, plant, equipment (PPE), intangible assets and equity income to control the firm's tax-related specifications. Each of these variables is scaled by lagged total assets. Firms with foreign income can avoid tax by refusing sending back the income to their own country. However, multinational firms may be taxed by several jurisdiction or face higher tax rates overseas. (Markle and Shackelford, 2009). We include property, plant, and equipment, intangible assets and equity income to capture the impact of a firm's investment activities on boo-tax differences. Based on the literature (Chen et al., 2010) accounting and tax rules are vary for these investment. Appendix A provides detailed definitions of all the variables.

\section{METHODOLOGY}

We employ difference in differences strategy (Bertrand et al. 2004) with multiple treatments at different times with different intensity in the various states. We run the following regression to examine the impact of trade secrets protection on corporate tax avoidance activities:

$$
\left(T A X_{i s t}\right)=\beta_{1} U T S A_{s t}+\beta_{2} S I Z E_{i t}+\beta_{3}(U T S A * S I Z E)_{i s t}+\beta_{4} X_{i t}+\alpha_{i s}+\alpha_{t}+\varepsilon_{i s t}
$$

where $i$, s and $t$ indicate firm, state and time, respectively. TAX $X_{i s t}$ is tax avoidance activities (measured by GAAP_ETR and CASH_ETR ) by firm $i$ in state $s$ in year $t$. UTSA st represents the increase in the legal protection of trade secrets arising from the UTSA being in effect. SIZE $E_{i t}$ represents the firms size (Measured by (1) the natural logarithm of sales which is deflated and centered around its sample mean or (2) one plus natural logarithm of number of employees which is centered around its sample mean) company $i$ in year $t$. $X_{i t}$ represents the control variables as explained in section 4.4 and appendix A. $\alpha_{i s}$ and $\alpha_{t}$ are company by state and year fixed effects, and $\varepsilon_{i s t}$ is an idiosyncratic error term. We estimate 
the standard errors by robust methods, clustered two ways, by state and company. In equation (1), the treatment group is the companies in states with the UTSA in effect, and the control group is the companies in states that did not have the UTSA in effect (including states that eventually did enact the UTSA, as well as states that never enacted the UTSA within the period of study). The coefficient of interest is $\beta_{3}$ which is the results of interaction between firm size and UTSA. Based on our hypothesis, we are expecting $\beta_{3}>0$.

\section{RESULTS}

\section{Descriptive Statistics of Sample}

Table 2 provides sample descriptive statistics. Panel A indicates that the number of observations, mean and standard deviation for the whole sample and Panel B indicates these variables for the whole sample excluding defense industry (SIC 372, 376 and 381). All control variables are winsorizes at the $1^{\text {st }}$ and $99^{\text {th }}$ percentile to remove the influence of extreme outliers. Appendix A provides all variables definition. The mean of GAAP_ETR and CASH_ETR are 0.287 and 0.320 , respectively for the whole sample. The mean of UTSA is 0.233 for the whole sample.

TABLE 2

\section{DESCRIPTIVE STATISTICS OF SAMPLE}

Panel A: All Sample

\begin{tabular}{cccc}
\hline \hline Variable & Obs & Mean & Std. Dev. \\
\hline Dependent Variables & & & \\
GAAP_ETR & 18,449 & 0.287 & 0.276 \\
CASH_ETR & 18,449 & 0.320 & 0.274 \\
Explanatory variable & & & \\
UTSA & 18,449 & 0.233 & 0.244 \\
Control Variables & & & \\
FOREIGN INCOME & 18,449 & 0.334 & 0.192 \\
PPE & 18,449 & 8134.960 & 21719.780 \\
SALES & 18,449 & 0.175 & 0.160 \\
LTLEV & 18,449 & 0.059 & 0.101 \\
CASH FLOW & 18,449 & 0.091 & 0.118 \\
CASH HOLDINGS & & & \\
INTANGIBLE ASSETS & 18,449 & 0.074 & 0.134 \\
EQUITY INCOME & 18,449 & 0.002 & 0.019 \\
LEV & 18,449 & 0.229 & 0.173 \\
MTB & 18,449 & 3.899 & 78.277 \\
ROA & 18,449 & 0.092 & 0.115 \\
\hline & & & \\
\hline
\end{tabular}

Panel B: All Sample Exclude Defense

\begin{tabular}{ccc}
\hline \hline Obs & Mean & Std. Dev \\
\hline 18,070 & 0.287 & 0.283 \\
18,070 & 0.317 & 0.272
\end{tabular}

$\begin{array}{lll}18,070 & 0.232 & 0.244\end{array}$

\begin{tabular}{ccc}
18,070 & 0.022 & 0.036 \\
18,070 & 0.340 & 0.194 \\
18,070 & 7746.510 & 22124.020 \\
18,070 & 0.174 & 0.162 \\
18,070 & 0.060 & 0.104 \\
18,070 & 0.092 & 0.119 \\
18,070 & 0.069 & 0.129 \\
18,070 & 0.002 & 0.019 \\
18,070 & 0.227 & 0.175 \\
18,070 & 4.023 & 80.829 \\
18,070 & 0.094 & 0.118 \\
\hline
\end{tabular}




\section{Univariate Results}

Table 3 reports the main results of our study estimated by ordinary least squares. Panel A of Table 3 reports the results on GAAP_ETR as the dependent variable. First, in column (1), we estimate the model without considering the interaction effect. As it was expected, UTSA by itself does not have any effect on dependent variable and it is consistent with Png (2017) study. In order to consider the interaction between UTSA and firm size (measured by the natural logarithm of sales which is deflated and centered around its sample mean), we run the second regression and the results are reported in column (2). The coefficient of UTSA is negative but not significant, while the coefficient of interaction variable is negative and statistically significant at $10 \%$ level. Indeed, trade secrets protection in larger firms reduce corporate tax avoidance activities measured by GAAP_ETR.

The effect of trade secrets protection on corporate tax avoidance activities might be different in high technology industries than other industries (Harhoff, 1998; Brown et al, 2009; Png, 2017). In order to capture this effect, following Hecker (1999) we define the high technology industries and consider the interaction of UTSA and an indicator of high-technology industries. In column (3), the coefficient of UTSA, which indicates the impact of UTSA on low-tech companies is not statistically significant and the coefficient of interaction which is the impact of UTSA in high tech companies is not significant (The coefficient of the UTSA for high-tech companies represents the incremental effect of the UTSA on hightech companies (relative to low-tech companies).

The mean of sale of the high-tech companies is around $63 \%$ those of the low-tech companies $(5,664.38$ and 8,983.415, respectively). So, in column (3) high-tech companies are confounded with smaller companies, and the coefficient of UTSA for high-tech companies also represents relatively smaller firms. To remedy this shortcoming, in column (4), we include the interaction of UTSA and firm size as well as interaction of UTSA and high-tech as well. The coefficient of the UTSA interacted with sales is negative and significant and interestingly as same as in the estimate in column (2).

As defense industries are heavily relying on the federal budget and extensively spread production across states to broaden political support, they may not be as sensitive as other industries to changes in trade secrets protection. Following Brown et al. (2009) and Png (2017), we exclude defense dominated industries (SIC 372, 376 and 381) from the sample. Column (5) reports the results for the whole sample excluding defense dominated industries. The coefficient of interaction of UTSA and sale is negative and statistically significant at 5\% level, which indicates, that trade secrets protection in larger firms (excluding defense-dominated industries) reduce corporate tax avoidance.

Panel B of Table 3 reports the results on CASH_ETR as dependent variable. The control variables are as same as the one that we have for panel A. So, we decided to reduce the table and report only main variables. The most striking points are the interaction of UTSA and sale in column (2) which is negative and statistically significant at 5\% level and the interaction of UTSA and high-technology industries in column (3) which is negative and statistically significant at $1 \%$ level. These results suggest that trade secret protection alleviate corporate tax avoidance measured by CASH_ETR in larger firms and hightechnology industries. 
TABLE 3

CORPORATE TAX AVOIDANCE, FIRM SIZE (SALE) AND UTSA

Panel A: GAAP_ETR

\begin{tabular}{|c|c|c|c|c|c|}
\hline Variables & $\begin{array}{c}(1) \\
\text { UTSA }\end{array}$ & $\begin{array}{c}(2) \\
\text { Sales }\end{array}$ & $\begin{array}{c}\text { (3) } \\
\text { High- tech }\end{array}$ & $\begin{array}{c}\text { (4) } \\
\text { Sales \& High- } \\
\text { tech }\end{array}$ & $\begin{array}{c}(5) \\
\text { Exclude } \\
\text { defense }\end{array}$ \\
\hline UTSA & $\begin{array}{l}-0.033 \\
(0.06)\end{array}$ & $\begin{array}{l}-0.078 \\
(0.067)\end{array}$ & $\begin{array}{l}-0.029 \\
(0.046)\end{array}$ & $\begin{array}{c}-0.081^{*} \\
(0.045)\end{array}$ & $\begin{array}{c}-0.097^{*} \\
(0.054)\end{array}$ \\
\hline UTSA x Sale $(\ln )$ & - & $\begin{array}{c}-0.038^{*} \\
(0.02)\end{array}$ & - & $\begin{array}{c}-0.038^{*} \\
(0.021)\end{array}$ & $\begin{array}{c}-0.053 * * \\
(0.023)\end{array}$ \\
\hline UTSA $x$ Hitech & - & - & $\begin{array}{l}-0.023 \\
(0.082)\end{array}$ & $\begin{array}{c}0.011 \\
(0.119)\end{array}$ & $\begin{array}{l}-0.147 \\
(0.27)\end{array}$ \\
\hline FOREIGN & & & & & \\
\hline INCOME & $\begin{array}{l}-0.246 \\
(0.309)\end{array}$ & $\begin{array}{l}-0.244 \\
(0.308)\end{array}$ & $\begin{array}{l}-0.245 \\
(0.309)\end{array}$ & $\begin{array}{l}-0.244 \\
(0.308)\end{array}$ & $\begin{array}{l}-0.242 \\
(0.31)\end{array}$ \\
\hline PPE & $\begin{array}{l}0.172^{*} \\
(0.089)\end{array}$ & $\begin{array}{l}0.173^{*} \\
(0.089)\end{array}$ & $\begin{array}{l}0.172^{*} \\
(0.089)\end{array}$ & $\begin{array}{c}0.173^{*} \\
(0.089)\end{array}$ & $\begin{array}{c}0.198^{* *} \\
(0.096)\end{array}$ \\
\hline SIZE (Sales) & $\begin{array}{c}-0.051^{* *} \\
(0.022)\end{array}$ & $\begin{array}{c}-0.043^{* *} \\
(0.021)\end{array}$ & $\begin{array}{c}-0.051^{* *} \\
(0.022)\end{array}$ & $\begin{array}{c}-0.043^{* *} \\
(0.021)\end{array}$ & $\begin{array}{l}-0.039^{*} \\
(0.021)\end{array}$ \\
\hline LTLEV & $\begin{array}{c}0.169 \\
(0.134) \\
-\end{array}$ & $\begin{array}{c}0.171 \\
(0.133)\end{array}$ & $\begin{array}{c}0.169 \\
(0.134)\end{array}$ & $\begin{array}{c}0.171 \\
(0.133)\end{array}$ & $\begin{array}{c}0.188 \\
(0.141)\end{array}$ \\
\hline CASH FLOW & $\begin{array}{c}9.920 * * * \\
(0.673)\end{array}$ & $\begin{array}{c}-9.919 * * * \\
(0.673)\end{array}$ & $\begin{array}{c}-9.919 * * * \\
(0.673)\end{array}$ & $\begin{array}{c}-9.920 * * * \\
(0.673)\end{array}$ & $\begin{array}{c}-9.936 * * * \\
(0.68)\end{array}$ \\
\hline CASH HOLDINGS & $\begin{array}{c}0.019 \\
(0.082)\end{array}$ & $\begin{array}{c}0.018 \\
(0.082)\end{array}$ & $\begin{array}{c}0.019 \\
(0.082)\end{array}$ & $\begin{array}{c}0.018 \\
(0.082)\end{array}$ & $\begin{array}{c}0.006 \\
(0.084)\end{array}$ \\
\hline INTANGIBLE & & & & & \\
\hline ASSETS & $\begin{array}{c}0.139 * * \\
(0.069)\end{array}$ & $\begin{array}{c}0.143 * * \\
(0.069)\end{array}$ & $\begin{array}{c}0.139 * * \\
(0.069)\end{array}$ & $\begin{array}{c}0.143 * * \\
(0.069)\end{array}$ & $\begin{array}{c}0.113 \\
(0.082)\end{array}$ \\
\hline EQUITY INCOME & $\begin{array}{c}-2.581^{* *} \\
(1.301)\end{array}$ & $\begin{array}{c}-2.576^{* *} \\
(1.301)\end{array}$ & $\begin{array}{c}-2.581^{* *} \\
(1.301)\end{array}$ & $\begin{array}{c}-2.576^{* *} \\
(1.301)\end{array}$ & $\begin{array}{c}-2.627^{* *} \\
(1.316)\end{array}$ \\
\hline LEV & $\begin{array}{c}0.093 \\
(0.125) \\
-\end{array}$ & $\begin{array}{c}0.09 \\
(0.125)\end{array}$ & $\begin{array}{c}0.093 \\
(0.125)\end{array}$ & $\begin{array}{c}0.09 \\
(0.125)\end{array}$ & $\begin{array}{l}0.073 \\
(0.13)\end{array}$ \\
\hline МТB & $\begin{array}{c}0.017 * * * \\
(0.004)\end{array}$ & $\begin{array}{c}-0.016^{* * *} \\
(0.004)\end{array}$ & $\begin{array}{c}-0.017 * * * \\
(0.004)\end{array}$ & $\begin{array}{c}-0.016 * * * \\
(0.004)\end{array}$ & $\begin{array}{c}-0.017 * * * \\
(0.004)\end{array}$ \\
\hline ROA & $\begin{array}{c}9.125 * * * \\
(0.547)\end{array}$ & $\begin{array}{c}9.125 * * * \\
(0.546)\end{array}$ & $\begin{array}{c}9.124 * * * \\
(0.547)\end{array}$ & $\begin{array}{c}9.125 * * * \\
(0.546)\end{array}$ & $\begin{array}{c}9.147 * * * \\
(0.554)\end{array}$ \\
\hline $\mathrm{R} 2$ & 0.34 & 0.34 & 0.34 & 0.34 & 0.34 \\
\hline Observations & 18,338 & 18,338 & 18,338 & 18,338 & 17,949 \\
\hline Companies & 1,330 & 1,330 & 1,330 & 1,330 & 1,311 \\
\hline Companies-states & 2,348 & 2,348 & 2,348 & 2,348 & 2,314 \\
\hline Company-state FE & Yes & Yes & Yes & Yes & Yes \\
\hline Year FE & Yes & Yes & Yes & Yes & Yes \\
\hline
\end{tabular}


Panel B: CASH ETR

(1)

(2)

(3)

(4)

(5)

\begin{tabular}{lccccc} 
Variables & UTSA & Sales & High- tech & $\begin{array}{c}\text { Sales \& High- } \\
\text { tech }\end{array}$ & $\begin{array}{c}\text { Exclude } \\
\text { defense }\end{array}$ \\
\hline UTSA & -0.033 & $-0.084^{* * *}$ & 0.029 & -0.019 & -0.025 \\
& $(0.060)$ & $(0.02)$ & $(0.01)$ & $(0.037)$ & $(0.059)$ \\
UTSA x Sale $(\ln )$ & & $-0.042^{* *}$ & & -0.035 & -0.027 \\
& & $(0.02)$ & & $(0.023)$ & $(0.032)$ \\
UTSA x Hitech & & & $-0.288^{* * *}$ & $-0.257^{* * *}$ & -0.204 \\
& & & $(0.018)$ & $(0.042)$ & $(0.157)$ \\
R2 & & & & & \\
Observations & 18,338 & 18,338 & 18,338 & 18,338 & 17,949 \\
Companies & 1,330 & 1,330 & 1,330 & 1,330 & 1,311 \\
Companies-states & 2,348 & 2,348 & 2,348 & 2,348 & 2,314 \\
All control variables & Yes & Yes & Yes & Yes & Yes \\
Company-state FE & Yes & Yes & Yes & Yes & Yes \\
Year FE & Yes & Yes & Yes & Yes & Yes \\
\hline
\end{tabular}

Based on the Business Research and Development Innovation Survey (BRDIS) conducted by the National Science Foundation's National Center for Science and Engineering, when looking specifically at large companies with 10,000 or more domestic employees and some R\&D expenditure, a lofty $80 \%$ of executives found that trade secrets were "very important". Therefore, we included firm size measured by one plus natural logarithm of number of employees that is centered around its sample mean. In panel A of Table 4, the coefficient of interaction between UTSA and Employee is negative and statistically significant for all models. In panel B, we can see the same situation excludes column (5). In addition, the coefficient of UTSA and high-tech industries is negative and significant at $1 \%$ level. Overall, the results are consistent with the ones that we have in Table 3. 
TABLE 4

CORPORATE TAX AVOIDANCE, FIRM SIZE (EMPLOYEE) AND UTSA

Panel A: GAAP ETR

\begin{tabular}{|c|c|c|c|c|c|}
\hline Variables & $\begin{array}{c}(1) \\
\text { UTSA }\end{array}$ & $\begin{array}{c}(2) \\
\text { Employee }\end{array}$ & $\begin{array}{c}\text { (3) } \\
\text { High- tech }\end{array}$ & $\begin{array}{c}\text { (4) } \\
\text { Employee \& High- } \\
\text { tech }\end{array}$ & $\begin{array}{c}(5) \\
\text { Exclude } \\
\text { defense }\end{array}$ \\
\hline UTSA & $\begin{array}{l}-0.012 \\
(0.067)\end{array}$ & $\begin{array}{c}0.078 \\
(0.085)\end{array}$ & $\begin{array}{c}0.003 \\
(0.052)\end{array}$ & $\begin{array}{c}0.08 \\
(0.065)\end{array}$ & $\begin{array}{l}0.126^{* *} \\
(0.056)\end{array}$ \\
\hline $\begin{array}{l}\text { UTSA x Employee } \\
(\ln )\end{array}$ & $\begin{array}{l}- \\
-\end{array}$ & $\begin{array}{l}-0.060 * \\
(0.031)\end{array}$ & $\begin{array}{l}- \\
-\end{array}$ & $\begin{array}{l}-0.059^{*} \\
(0.034)\end{array}$ & $\begin{array}{c}-0.091 * * \\
(0.039)\end{array}$ \\
\hline UTSA $x$ Hitech & - & - & $\begin{array}{c}-0.07 \\
(0.088)\end{array}$ & $\begin{array}{l}-0.018 \\
(0.142)\end{array}$ & $\begin{array}{l}-0.205 \\
(0.266)\end{array}$ \\
\hline FOREIGN INCOME & $\begin{array}{c}-0.322 \\
(0.301)\end{array}$ & $\begin{array}{c}-0.326 \\
(0.3)\end{array}$ & $\begin{array}{l}-0.32 \\
(0.302)\end{array}$ & $\begin{array}{l}-0.326 \\
(0.301)\end{array}$ & $\begin{array}{l}-0.334 \\
(0.301)\end{array}$ \\
\hline PPE & $\begin{array}{l}0.136 \\
(0.092)\end{array}$ & $\begin{array}{c}0.137 \\
(0.092)\end{array}$ & $\begin{array}{c}0.135 \\
(0.092)\end{array}$ & $\begin{array}{c}0.137 \\
(0.092)\end{array}$ & $\begin{array}{c}0.161 \\
(0.099)\end{array}$ \\
\hline SIZE (Employees) & $\begin{array}{l}-0.033 \\
(0.036)\end{array}$ & $\begin{array}{l}-0.019 \\
(0.034)\end{array}$ & $\begin{array}{l}-0.033 \\
(0.035)\end{array}$ & $\begin{array}{l}-0.019 \\
(0.034)\end{array}$ & $\begin{array}{l}-0.013 \\
(0.037)\end{array}$ \\
\hline LTLEV & $\begin{array}{c}0.133 \\
(0.148)\end{array}$ & $\begin{array}{c}0.136 \\
(0.148)\end{array}$ & $\begin{array}{c}0.133 \\
(0.148)\end{array}$ & $\begin{array}{c}0.136 \\
(0.148)\end{array}$ & $\begin{array}{c}0.149 \\
(0.157)\end{array}$ \\
\hline CASH FLOW & $\begin{array}{c}-9.882 * * * \\
(0.7)\end{array}$ & $\begin{array}{c}-9.881^{* * *} \\
(0.7)\end{array}$ & $\begin{array}{c}-9.878 * * * \\
(0.7)\end{array}$ & $\begin{array}{c}-9.880^{* * *} \\
(0.7)\end{array}$ & $\begin{array}{c}-9.878 * * * \\
(0.705)\end{array}$ \\
\hline CASH HOLDINGS & $\begin{array}{l}-0.001 \\
(0.077)\end{array}$ & $\begin{array}{l}-0.001 \\
(0.077)\end{array}$ & $\begin{array}{l}-0.001 \\
(0.077)\end{array}$ & $\begin{array}{l}-0.001 \\
(0.077)\end{array}$ & $\begin{array}{l}-0.018 \\
(0.078)\end{array}$ \\
\hline INTANGIBLE & & & & & \\
\hline ASSETS & $\begin{array}{l}0.127^{*} \\
(0.074)\end{array}$ & $\begin{array}{l}0.132 * \\
(0.073)\end{array}$ & $\begin{array}{l}0.127 * \\
(0.074)\end{array}$ & $\begin{array}{l}0.132 * \\
(0.074)\end{array}$ & $\begin{array}{c}0.101 \\
(0.087)\end{array}$ \\
\hline EQUITY INCOME & $\begin{array}{c}-2.934 * * \\
(1.306)\end{array}$ & $\begin{array}{c}-2.922 * * \\
(1.3)\end{array}$ & $\begin{array}{c}-2.932 * * \\
(1.307)\end{array}$ & $\begin{array}{c}-2.922 * * \\
(1.3)\end{array}$ & $\begin{array}{c}-2.999 * * \\
(1.319)\end{array}$ \\
\hline LEV & $\begin{array}{l}0.187 \\
(0.14)\end{array}$ & $\begin{array}{l}0.184 \\
(0.14)\end{array}$ & $\begin{array}{l}0.187 \\
(0.14)\end{array}$ & $\begin{array}{l}0.184 \\
(0.14)\end{array}$ & $\begin{array}{c}0.174 \\
(0.147)\end{array}$ \\
\hline MTB & $\begin{array}{c}-0.017 * * * \\
(0.004)\end{array}$ & $\begin{array}{c}-0.017 * * * \\
(0.004)\end{array}$ & $\begin{array}{c}-0.017 * * * \\
(0.004)\end{array}$ & $\begin{array}{c}-0.017 * * * \\
(0.004)\end{array}$ & $\begin{array}{c}-0.017 * * * \\
(0.004)\end{array}$ \\
\hline ROA & $\begin{array}{c}9.216^{* * *} \\
(0.568)\end{array}$ & $\begin{array}{c}9.216^{* * *} \\
(0.568)\end{array}$ & $\begin{array}{c}9.213 * * * \\
(0.568)\end{array}$ & $\begin{array}{c}9.215^{* * *} \\
(0.568)\end{array}$ & $\begin{array}{c}9.239^{* * *} \\
(0.574)\end{array}$ \\
\hline $\mathrm{R} 2$ & 0.31 & 0.31 & 0.31 & 0.31 & 0.31 \\
\hline Observations & 18,338 & 18,338 & 18,338 & 18,338 & 17,949 \\
\hline Companies & 1,330 & 1,330 & 1,330 & 1,330 & 1,311 \\
\hline Companies-states & 2,348 & 2,348 & 2,348 & 2,348 & 2,314 \\
\hline Company-state FE & Yes & Yes & Yes & Yes & Yes \\
\hline Year FE & Yes & Yes & Yes & Yes & Yes \\
\hline
\end{tabular}


Panel B: CASH_ETR

(1)

\begin{tabular}{|c|c|c|c|c|c|}
\hline Variables & UTSA & Employee & High- tech & $\begin{array}{l}\text { Employee \& High- } \\
\text { tech }\end{array}$ & $\begin{array}{l}\text { Exclude } \\
\text { defense }\end{array}$ \\
\hline UTSA & $\begin{array}{l}-0.044 \\
(0.030)\end{array}$ & $\begin{array}{c}0.045 \\
(0.024)\end{array}$ & $\begin{array}{c}0.018 \\
(0.009)\end{array}$ & $\begin{array}{c}0.080 \\
(0.021)\end{array}$ & $\begin{array}{c}0.045 \\
(0.036)\end{array}$ \\
\hline $\begin{array}{l}\text { UTSA x Employee } \\
(\ln )\end{array}$ & $\begin{array}{l}- \\
-\end{array}$ & $\begin{array}{c}-0.057 * * * \\
(0.014)\end{array}$ & $\begin{array}{l}- \\
-\end{array}$ & $\begin{array}{c}-0.046^{* *} \\
(0.018)\end{array}$ & $\begin{array}{l}-0.032 \\
(0.033)\end{array}$ \\
\hline UTSA x Hitech & $\begin{array}{l}- \\
-\end{array}$ & - & $\begin{array}{c}-0.281 * * * \\
(0.028)\end{array}$ & $\begin{array}{c}-0.241 * * * \\
(0.052)\end{array}$ & $\begin{array}{l}-0.19 \\
(0.165)\end{array}$ \\
\hline $\mathrm{R} 2$ & 0.07 & 0.07 & 0.07 & 0.07 & 0.07 \\
\hline Observations & 18,338 & 18,338 & 18,338 & 18,338 & 17,949 \\
\hline Companies & 1,330 & 1,330 & 1,330 & 1,330 & 1,311 \\
\hline Companies-states & 2,348 & 2,348 & 2,348 & 2,348 & 2,314 \\
\hline All control variables & Yes & Yes & Yes & Yes & Yes \\
\hline Company-state FE & Yes & Yes & Yes & Yes & Yes \\
\hline Year FE & Yes & Yes & Yes & Yes & Yes \\
\hline
\end{tabular}

\section{CONCLUSION AND IMPLICATION}

We examine the relationship between increased trade secrets protection and tax avoidance by companies. In order to isolate the relationship between these two variables, we exploit the state-staggered adoption of the UTSA, a state-level trade secrets law. The UTSA provides numerous trade secrets protections, but most significantly it defines what a trade secret is, it specifically characterizes what misappropriation is, and it clarifies the remedies of firms who have had their trade secrets misappropriated.

Based on survey evidence from the BRDIS and recent empirical work by Png $(2016,2017)$, Dass et al. (2015), and Figueroa and Serrano (2013), we consider the impact of the UTSA on tax avoidance by companies. We do this by first analyzing the effect of firm size on tax avoidance by considering two proxies for firm size. These two proxies are the natural logarithm of sales and the natural logarithm of one plus number of employees. Next, we utilize two alternative measures of tax avoidance, each based on effective tax rate. These two measures are GAAP effective tax rate and CASH effective tax rate.

We employ a difference-in-differences strategy with multiple treatments at different times with different intensity in the various states. This strategy allows us to contrast the tax avoidance activities of large firms located in UTSA states with those large firms headquartered in non-UTSA states. We find that the UTSA, by itself, does not have any effect on tax avoidance, but when combined with firm size, we found that larger companies engage in less tax avoidance. Moreover, we document the relationship between different industries and their tax avoidance activities. Namely, we find that large hightechnology companies tend to engage in less tax avoidance activities than large companies in other industries. Moreover, we excluded defense industries from our analysis because companies in these industries rely heavily on the federal budget and are far less sensitive to changes in trade secrets protection. This indicates a more positive future outlook by those companies that are large and located in states with UTSA protection.

Overall, the results from these tests suggest that the UTSA decreases tax avoidance activities on the part of large firms. As such, our research provides a compelling reason for state legislatures to enact the additional protections afforded by the UTSA. 


\section{REFRENCES}

Alimov, A. (2014). Product market competition and the value of corporate cash: Evidence from trade liberalization. Journal of Corporate Finance, 25, 122-139.

Andersen, J. E., \& E. Van Wincoop. (2004). Trade costs. Journal of Economic Literature, 62, 691-751.

Badertscher, B., Katz, S., \& Rego, S., (2013). The separation of ownership and control and corporate tax avoidance. Journal of Accounting and Economics, 56, 228-250.

Bertrand, M., Duflo, E., \& Mullainathan, S. (2004). How much should we trust differences-in-differences estimates?. The Quarterly journal of economics, 119(1), 249-275.

Bernard, A. B., Jensen, J. B., \& Schott, P. K. 2006. Trade costs, firms and productivity. Journal of monetary Economics, 53(5), 917-937.

Brenner, J.S. (2001). The Doctrine of Inevitable Disclosure and its Inevitable Effect on Companies and People. Law and Business Review of the Americas, 668-69.

Brown, J. R., Fazzari, S. M., \& Petersen, B. C. (2009). Financing innovation and growth: Cash flow, external equity, and the 1990s R\&D boom. The Journal of Finance, 64(1), 151-185.

Cen, L., Maydew, E. L., Zhang, L., \& Zuo, L. (2016). Customer-supplier relationships and corporate tax avoidance. Journal of Financial Economics, 000, 1-18.

Chang, Y. K., Chen, Y. L., Chou, R. K., \& Huang, T. H. (2015). Corporate governance, product market competition and dynamic capital structure. International Review of Economics \& Finance, 38, 44-55.

Chen, S., Chen, X., Cheng, Q., \& Shevlin, T. (2010). Are family firms more tax aggressive than nonfamily firms? Journal of Financial Economics, 95(1), 41-61.

Cheng, C. A., Huang, H. H., Li, Y., \& Stanfield, J. (2012). The effect of hedge fund activism on corporate tax avoidance. The Accounting Review, 87(5), 1493-1526.

Contigiani, A, Barankay, I, Hsu D. H. (2016) Trade secrets and innovation: Evidence from the 'Inevitable Disclosure' doctrine. Working paper, University of Pennsylvania, Philadelphia.

Correa, M. (1963). Protection of Trade Secrets. Business Law, 53, 531.

Desai, M., Dharmapala, D. (2006). Corporate tax avoidance and high-powered incentives. Journal of Financial Economics 79(1), 145-179.

Desai, M., \& Dharmapala, D. (2009). Corporate tax avoidance and firm value. Review of Economics and Statistics, 91, 537-546.

Developments in the Law: Competitive Torts. (1964). IV. Misappropriation of Commercial Intangibles, B. Trade Secrets. Harvard Law Review, 77(5).

Dyreng, S.D., Hanlon, M., \& Maydew, E.L. (2008). Long-run corporate tax avoidance. The Accounting Review, 83(1), 61-82.

Figueroa, N., \& Serrano, C. J. (2013) Patent trading flows of small and large firms. NBER Working Paper 18982, National Bureau of Economic Research, Cambridge, MA.

Frank, M., Lynch, L., \& Rego, S. (2009). Tax reporting aggressiveness and its relation to aggressive financial reporting. The Accounting Review, 84, 467-496.

Gao, H., \& Ma, Y. (2016) Human capital driven acquisition: Evidence from the Inevitable Disclosure Doctrine. Working paper, Nanyang Technological University, Singapore.

Graham, J., \& Tucker, A. (2006). Tax shelters and corporate debt policy. Journal of Financial Economics, 81, 563-594.

Giroud, X., \& Mueller, H. M. (2011). Corporate governance, product market competition, and equity prices. The Journal of Finance, 66(2), 563-600.

Gupta, S., \& Newberry, K. (1997). Determinants of the variability in corporate effective tax rates: Evidence from longitudinal data. Journal of Accounting and Public Policy, 16(1), 1-34.

Guenrsey, S. (2017). Are some things best kept secret? The effect of the uniform trade secrets act on financial leverage. Working paper, Oklahoma State University, USA. 
Guo, F., Nanda, V. K., \& Pevzner, M. (2016). The effects of trade secret protections on financial reporting opacity: Evidence from a natural experiment. Working paper, University of Kansas, Lawrence.

Hall, B. H., Helmers, C., Rogers, M., \& Sena, V. (2014). The choice between formal and informal intellectual property: A review. J. Econom. Lit. 52(2), 375-423.

Hanlon, M., \& Slemrod, J. (2009). What does tax aggressiveness signal? Evidence from stock price reactions to news about tax shelter involvement. Journal of Public Economics, 93, 126-141.

Hanlon, M., \& Heitzman, S. (2010). Review of tax research. Journal of Accounting and Economics 50, 127-178.

Hanlon, M., Maydew, E. L., \& Saavedra, D. (2016). The taxman cometh: does tax uncertainty affect corporate cash holdings? Unpublished working paper. University of California, Los Angeles

Harhoff, D. (1998). R\&D and productivity in German manufacturing firms. Economics of Innovation and New Technology, 6(1), 29-50.

Hasan, I., Hoi, C. K. S., Wu, Q., \& Zhang, H. (2014). Beauty is in the eye of the beholder: The effect of corporate tax avoidance on the cost of bank loans. Journal of Financial Economics, 113(1), 109130.

Hecker, D. (1999). High-technology employment: a broader view. Monthly Lab. Rev., 122, 18.

Higgins, D., Omer, T., \& Phillips, J. (2015). The influence of a firm's business strategy on its tax aggressiveness. Contemporary Accounting Research, 32, 674-702.

Hoberg, G., Philips, g., \& Prabhala, N. (2014). Product market threats, payouts and financial flexibility. The Journal of Finance, 69, 293-324.

Huang, H., Lobo, g., Wang, C., \& Xie, H. (2016). Customer concentration and corporate tax avoidance. Journal of Banking and Finance, 72, 184-200.

Jaffe, A. B. (1986) Technological opportunity and spillovers of R\&D. American Economics Review, 76(5), 984-1001.

Jager, M. F. (1988). Trade Secrets Law, § 1.04.

Kim, J. B., Li, Y., \& Zhang, L. (2011). Corporate tax avoidance and stock price crash risk: Firm-level analysis. Journal of Financial Economics, 100(3), 639-662.

Klasa, S., Ortiz-Molina, H., Serfling, M., \& Srinivasan, S. (2017) Protection of trade secrets and capital structure decisions. Working paper, University of Arizona, Tucson.

Laksmana, I., \& Yang, Y. W. (2014). Product market competition and earnings management: Evidence from discretionary accruals and real activity manipulation. Advances in Accounting, 30(2), 263275.

Lin, C., Wei, L., \& Wu, H. (2016). Operational uncertainty and managerial incentives in information production. Working Paper, University of Hong Kong, Pokfulam.

Lisowsky, P. (2010). Seeking shelter: Empirically modeling tax shelters using financial statement information. The Accounting Review, 85(5), 1693-1720.

Markle, K., \& Shackelford, D. (2009). Does the Domicile of a Multinational Affect its Worldwide Corporate Income Tax Liability? University of North Carolina working paper.

Manzon, G., \& Plesko, G. (2002). The relation between financial and tax reporting measures of income. Tax Law Review, 55, 175-214.

McGuire, S. T., Omer, T. C., \& Wang, D. (2012). Tax avoidance: does tax-specific industry expertise make a difference? The Accounting Review, 87, 975-1003.

Milgrim, R. (1968). Trade Secrets.

Mills, L. (1998). Book-tax differences and internal revenue service adjustments. Journal of Accounting Research, 36, 343-356.

National Science Foundation, National Center for Science and Engineering Statistics, and U.S. Census Bureau, Business R\&D and Innovation Survey, 2013.

Pace, C. R. J. (1995). The Case for a Federal Trade Secrets Act. Harvard Journal of Law and Technology, 427. 
Phillips, J. D. (2003). Corporate tax-planning effectiveness: The role of compensation-based incentives. The Accounting Review, 78(3), 847-874.

Png, I.P., \& Samila, S. (2015) Trade secrets law and mobility: Evidence from 'Inevitable Disclosure'. Working paper, National University of Singapore, Singapore.

Png, I.P. (2016) Secrecy and patents: Evidence from the Uniform Trade Secrets Act. Working paper, National University of Singapore, Singapore.

Png, I. P. (2017) Law and innovation: Evidence from state trade secrets laws. Review of Economics and Statistics. 99(1), 167-179.

Qui, B., \& Wang, T. (2017). Does knowledge protection benefit shareholders? Evidence from stock market reaction and firm investment in knowledge assets." Working paper, Finance and Economics Discussion Series 2017-012.

Restatement (First) of Torts, 1934. § 1 comment a, comment b.

Restatement (Third) of Unfair Competition $\S 1,1995$. Comment a.

Restatement (First) of Torts, 1939. Division Nine, interference with Business Relations.

Restatement (First) of Torts, 1934. § 757.

Roberson, K. A. (2001). South Carolina's Inevitable Adoption of the Inevitable Disclosure Doctrine: Balancing Protection of Trade Secrets with Freedom of Employment. South Carolina Law Review, 909.

Richardson, G., Taylor, G., \& Lanis, R. (2013). The impact of board of director oversight characteristics on corporate tax aggressiveness: an empirical analysis. Journal of Accounting and Public Policy, 32(3), 68-88.

Rego, S. O. (2003). Tax-avoidance activities of US multinational corporations. Contemporary Accounting Research, 20(4), 805-833.

Rego, S. O., \& Wilson, R. 2012. Equity risk incentives and corporate tax aggressiveness. Journal of Accounting Research, 50(3), 775-810.

Sandeen, S. (2010). The Evolution of Trade Secret Law and Why Courts Commit Error When They Do Not Follow the Uniform Trade Secrets Act. Hamline Law Review, 519.

Transcript of Proceedings in Committee of the Whole, Uniform Trade Secrets Protection Act, 1978. Notes 216-233.

Uniform Trade Secrets Act § 1(4), 1(2)(i), 1(2)(ii)(B)(III), 1(2)(ii)(B)(III), 1(2)(ii)(C), $2,4$.

Wilson, R. J. (2009). An examination of corporate tax shelter participants. The Accounting Review 84(3), 969-999.

35 U.S. Const. § 1-390

35 U.S.C. $\S 101$

17 U.S.C. § 101-1332

17 U.S.C. $\S \S 102-103$ (2000)

15 U.S.C. $\S 1051-1141 n$ 


\section{APPENDIX A}

Variable Definition

Trade secrets

variable

UTSA

The change in state-specific trade secrets protection after the enactment of the Uniform Trade Secrets Act

Tax variables

GAAP ETR

CASH ETR

GAAP effective tax rate: TXT/ (PI-SPI)

Cash effective tax rate: TXPD/ (PI-SPI)

\section{Control variables}

SIZE (sales) The natural logarithm of sale, centerd by substracting out its sample mean

SIZE (employee) The natural logarithm of one plus the total number of employees, centerd by substrating out its sample mean

LEV Financial leverage, calculated as long-term debt (DLTT) plus current debt (DLC) scaled by total assets (AT)

MTB Market-to-book ratio at the beginning of the year, calculated as the market value of equity (Compustat PRCC_F $\times$ CSHO) divided by the book value of equity (Compustat CEQ)

ROA Return on assets, calculated as pre-tax income (PI) divided by lagged total assets (AT)

Foreign income Foreign Income (PIFO), scaled by lagged assets (AT)

PPE

Net property, plant, and equipment, calculated as Compustat PPENT scaled by lagged total assets (AT)

Intangible assets Intangible assets, calculated as Compustat INTANO plus GDWL scaled by lagged total assets (AT).

Equity income Equity Income in earnings (ESUB), scaled by lagged assets(AT)

Cash holdings Cash and short term investments (CHE) divided by total assets

Long-term leverage Long-term debt (DLTT) divided by total assets

Cash flow Income before extraordinary items (IBC) divided by total assets 


\section{APPENDIX B}

\section{Index of Legal Protection of Trade Secrets}

This table is an exact reproduction from Table A1 in the appendix of Png (2017). It provides the criteria used in the construction of the state-level trade secrets protection index. The values specific to each state are summed across the six unique items over time. The first iteration of this summation process yields the level of trade secrets protection provided by common law. Next, if a state passes the UTSA, the items are re-evaluated and a post-enactment index value is calculated. The change in the value of the index captures state-level exogenous variation in trade secrets protection.

\begin{tabular}{|c|c|c|c|}
\hline Dimension & Item & Coding & Sources \\
\hline $\begin{array}{l}\text { Substantive } \\
\text { law }\end{array}$ & $\begin{array}{l}\text { Whether information must } \\
\text { be in actual or intended } \\
\text { business use to be protected } \\
\text { as trade secret. }\end{array}$ & $\begin{array}{l}=0 \text { if information must be } \\
\text { in actual or intended use, }= \\
1 \text { otherwise. }\end{array}$ & $\begin{array}{l}\text { ULA (Uniform Laws } \\
\text { Annotated); Pedowitz et al. } \\
\text { 1997; Malsberger et al. } \\
2006\end{array}$ \\
\hline $\begin{array}{l}\text { Substantive } \\
\text { law }\end{array}$ & $\begin{array}{l}\text { Whether reasonable efforts } \\
\text { are required to maintain } \\
\text { secrecy. }\end{array}$ & $\begin{array}{l}=0 \text { if reasonable efforts } \\
\text { required, }=1 \text { otherwise. }\end{array}$ & $\begin{array}{l}\text { ULA; Pedowitz et al. 1997; } \\
\text { Malsberger et al. } 2006\end{array}$ \\
\hline $\begin{array}{l}\text { Substantive } \\
\text { law }\end{array}$ & $\begin{array}{l}\text { Whether information must } \\
\text { be used or disclosed for it to } \\
\text { be deemed to have been } \\
\text { misappropriated. }\end{array}$ & $\begin{array}{l}=0 \text { if information must be } \\
\text { used or disclosed, }=1 \text { if } \\
\text { includes mere improper } \\
\text { acquisition or no } \\
\text { requirement. }\end{array}$ & $\begin{array}{l}\text { ULA; Pedowitz et al. 1997; } \\
\text { Malsberger et al. } 2006\end{array}$ \\
\hline $\begin{array}{l}\text { Civil } \\
\text { procedure }\end{array}$ & $\begin{array}{l}\text { Limitation on the time for } \\
\text { the owner to take legal } \\
\text { action for misappropriation. }\end{array}$ & $\begin{array}{l}\text { Number of years divided } \\
\text { by three. }\end{array}$ & $\begin{array}{l}\text { ULA; Pedowitz et al. 1997; } \\
\text { Malsberger et al. } 2006\end{array}$ \\
\hline Remedies & $\begin{array}{l}\text { Whether an injunction is } \\
\text { limited to eliminating the } \\
\text { advantage from } \\
\text { misappropriation. }\end{array}$ & $=0$ if yes, $=1$ otherwise. & $\begin{array}{l}\text { Pedowitz et al. } 1997 \text {; } \\
\text { Malsberger et al. } 2006\end{array}$ \\
\hline Remedies & $\begin{array}{l}\text { Multiple of actual damages } \\
\text { available in punitive } \\
\text { damages. }\end{array}$ & $\begin{array}{l}\text { Number of years divided } \\
\text { by six. }\end{array}$ & $\begin{array}{l}\text { Pedowitz et al. } 1997 ; \\
\text { Malsberger et al. } 2006\end{array}$ \\
\hline
\end{tabular}

